\title{
Analysis of Mercury toxicity in the wild Population of Black-headed Oriole Oriolus brachyrhynchus (Swainson, I837) from some selected community in Benue State, Nigeria
}

\begin{abstract}
Analysis of mercury concentration in Black-headed oriole Oriolus brachyrhynchus was carried out using Atomic Absorption Spectrometry to determine the bioaccumulation level in the feather, liver heart, skin, carcass, nestling feather and egg so as to say which of these parts carried more contaminant. A total of 30 birds were trapped using mist net and 150 of these parts were obtained. A total of 9 eggs and 9 nestling were also collected from different nest in the study areas for investigation. Descriptive statistics were used to express mercury concentration $\mathrm{mg} / \mathrm{kg}$ in the selected parts. Mercury concentration in the different organs of the bird caught in the three sample sites are as follows: feather has the highest mean values of $3.76 \pm 1.50 \mathrm{mg} / \mathrm{kg}$ at Daudu, skin; $0.43 \pm 0.67 \mathrm{mg} / \mathrm{kg}$ at Daudu, carcass; $7.05 \pm 1.65 \mathrm{mg} / \mathrm{kg}$ at Buruku, egg; $0.11 \pm 0.02 \mathrm{mg} / \mathrm{kg}$ at Daudu and nestling feather; $3.80 \pm 1.47 \mathrm{mg} / \mathrm{kg}$ at Daudu. Mercury concentration in the heart from the three study sites was below detection limit of $0.001 \mu \mathrm{g} / 1$ whereas mercury concentration in the liver does not differ significantly. A significant correlation $\left(\mathrm{r}^{2}=0.810\right)$ existed between the feather and the carcass at $(\mathrm{P}<0.01)$ and also $\left(\mathrm{r}^{2}=-0.997\right)$ between carcass and liver at $(\mathrm{P}<0.05)$. Mercury concentration has the highest mean value of $2.53 \pm 0.00 \mathrm{mg} / \mathrm{kg}$ in maize at Daudu, and in rice; it was below detection limit, while guinea corn; $4.58 \pm 0.23 \mathrm{mg} / \mathrm{kg}$ also at Daudu. The concentration in soil and water was highest at Daudu with a mean of $8.11 \mathrm{mg} / \mathrm{kg}$ and $0.08 \mathrm{mg} / \mathrm{l}$ respectively. However, mercury concentration in the bird species in the study areas has exceeded the permissible limit of WHO standard of $0.5 \mathrm{mg} / \mathrm{kg}$, and far above WHO permissible level for crop $0.02 \mathrm{mg} / \mathrm{kg}$ and water $0.002 \mathrm{mg} / 1$ which calls for concern, as cereals are the major feed consumed by some bird species in the study areas. This calls for continuous monitoring.
\end{abstract}

Volume 3 Issue I - 2018

\author{
Egwumah FA, Egwumah PO, Orsar T] \\ Department of Wildlife and Range Management, University of \\ Agriculture Makurdi, Benue State, Nigeria
}

\begin{abstract}
Correspondence: Egwumah Attah Francis, Department of Wildlife and Range Management, University of Agriculture Makurdi, Benue State, Nigeria, Tel +234706462 I 278, Email egwumahattah@gmail.com
\end{abstract}

Received: December II, 2017 | Published: January 23, 2018

Keywords: mercury, analysis, black-headed, population, toxicity

Abbreviations: WF, weight of feather; WL, weight of liver; WC, weight of carcass; WS, weight of skin; WH, weight of heart; $\mathrm{HgCF}$, mercury concentration in feather; $\mathrm{HgCC}$, mercury concentration in carcass; $\mathrm{HgCL}$, mercury concentration in liver; $\mathrm{HgCS}$, mercury concentration in skin

\section{Introduction}

Mercury contamination in wild birds has long been recognized as a serious predicament in terms of pollution. Emission of mercury is still being observed ${ }^{1-3}$ in order to reduce the rate of environmental pollution. Birds can be exposed externally, by physical contact, and internally, by consumption of contaminated feed. ${ }^{4}$ Mercury can be bioaccumulated and biomagnified in the ecosystems leading to wildlife being exposed to it, and this may harm birds and even lead to population declines ${ }^{5}$ in most cases. The tendency of mercury to accumulate in bird species depends on the intake and the rate of elimination from the body. ${ }^{6}$ Basically, transportation of mercury in birds occurs through the blood where the ions are generally bound to proteins. This contaminant is brought into contact with the organs and tissues of the bird and as a result they are accumulated at different degree in different organs and tissues of the bird ${ }^{7}$ but, it is a function of the duration of exposure.
The toxicity of mercury is due to its ability to cause, oxidative damage to living tissues. For example; it promotes lipid peroxidation, DNA damage, enzyme inactivation and the oxidation of protein sulfhydryl groups as reported by Kaoud. ${ }^{7}$ In addition, it stimulates lethargy and the disruption in the endocrine system as well as a change in mating and parenting behavior in wild birds. ${ }^{8-11}$ For over 20 years, wild birds have decline considerably in population. ${ }^{12}$ These declines have been largely attributed to changes in agricultural practices ${ }^{12,13}$ and other anthropogenic activities. Agricultural practices involving the application of fertilizers and pesticides increases mercury concentration. Mercury concentrations in birds have been assessed by using various parts such as liver, kidney, tissues muscle, bone, fat, eggs, feathers and excrements. ${ }^{14,15}$ Black-headed orioles have a conservation status of least concern. It was selected for this research work because they are farmland dependent birds. Rice is not an aquatic plant, although it has been grown under flooded conditions for over 5000 years ${ }^{16}$ which is responsible for accumulation of mercury in rice. Apart from that, fungicides also play a vital role in mercury contamination in birds. Fungicides vary enormously in their potential for causing adverse effects in birds. The main objective of the study is to determine, weather the mercury concentration in the various organs of the birds differs with location and to determine the concentration of mercury in the environment utilized by some wild birds. 


\section{Materials and methods}

\section{Study area}

The study sites were located at Buruku on Latitude $7^{\circ} 27^{\prime} 35.6^{\prime \prime} \mathrm{N}$ and Longitude $9^{\circ} 12^{\prime} 20.5^{\prime \prime} \mathrm{E}$ in Buruku LGA, Daudu on Latitude $7^{\circ}$ 55' 53.0" $\mathrm{N}$ and Longitude $8^{\circ} 34^{\prime}$ 53.9" $\mathrm{E}$ in Guma LGA and Adega on Latitude $7^{\circ} 01^{\prime} 47.4^{\prime \prime} \mathrm{N}$ and Longitude $8^{\circ} 15^{\prime} 28.0^{\prime \prime} \mathrm{E}$ in Obi LGA of Benue State.

\section{Sampling technique}

Using selective sampling technique which is a non- probability sampling techniques based on personal choice without statistical bias. ${ }^{17}$ The study sites are not a conservation area and the local people are predominantly peasant farmers. A total of 28 hectares of farmland area was selected in each of these study sites. The 28 ha sampling plot is further divided into four sampling units of 7 ha, where bird capturing activities took place and ethical permit was obtained from Department of Forest protection and Management Ministry of Water resources and Environment in Makurdi, Benue State Nigeria. A mist net was set in each sampling unit and the net was checked after every 2-3 hours to search for a catch. Three replicates of nestling feathers and eggs collected from the tree species used as breeding ground by birds were stored in plastic sampling bottles. Ten birds was trapped using mist net at the various locations. The birds were slaughtered and weighed before they were defeathered, the feathers were dried in an oven and kept in polyethene bags and sealed tightly. The defeathered birds are dissected to remove the skin, heart and liver which were kept in a polyethene bags and stored in a dessicator for mercury analysis. Three replicates of rice, maize and guinea corn were also collected directly from different farmland as component of biological pathway for mercury contamination in some wild birds. Three replicates of water and soil samples were equally collected from the study areas for mercury concentration investigation as component of biological pathway.

\section{Sample cleaning}

The feather samples collected were cut into about $0.3 \mathrm{~cm}$ using a stainless steel scissors and first rinsed in ethanol, then washed three times in distilled water and then finally washed again in ethanol in accordance to the recommendation of International Atomic Energy Agency. ${ }^{18}$ These was placed in crucibles and dried in an oven at $75^{\circ} \mathrm{C} \pm 5^{\circ} \mathrm{C}$ for 25 minutes. About $0.2 \mathrm{mg}$ of treated feather sample was weighed and stored in an inert plastic container of $10 \mathrm{~cm}^{3}$ capacity, corked tightly and kept for mercury analysis using a Flame Atomic Absorption Spectrometry.

The skin, heart, liver and the carcass after the vital parts are removed were dried in an oven equipped with circulation system at $60^{\circ} \mathrm{C}$ for $48 \mathrm{~h}$, and homogenized using a porcelain mortar. Approximately $0.2 \mathrm{mg}$ of dry sample was treated with $7 \mathrm{ml}$ of concentrated nitric acid and heated for 20min in the microwave oven, as described by Edison \& Egwumah. ${ }^{19,20}$ The resultant solution was transferred into a $100 \mathrm{ml}$ volumetric flask and made up to volume with distil water. The solution was stored at $4^{\circ} \mathrm{C}$ in polyethylene bottles until mercury was analyzed, using a Flame Atomic Absorption Spectrometry. The same procedure and quality control described by Egwumah ${ }^{20}$ was followed for rice, maize, guinea corn, water and soil collected and digested for this study. A Flame Atomic Absorption Spectrometry (AAS), with detection limit of $0.001 \mathrm{mg} / \mathrm{L}$ for mercury made by Biotech Engineering Management Co. Ltd. (UK) Model: Phoenix 986 was used.

\section{Experimental design and data analysis}

Using Randomized Complete Block Design (RCBD) the data was analyzed, where locations represented the blocks and the bird species the treatment. Pearson correlation was use to test the correlation between weight of organs and mercury concentrations in organs $(\mathrm{P}<0.05)$. One way ANOVA was used to determine, weather mercury concentration in different parts of the bird differs with location. Summary statistics of mercury concentration $(\mathrm{mg} / \mathrm{kg})$ in cereal was express in mean values with their respective standard deviations, minimum and maximum values.

\section{Results}

A total of 168 organs were obtained from Black headed oriole trapped from different location in Benue State for mercury concentration. Table 1 shows the summary statistics of mercury concentration in selected organs of expressed in samples $(\mathrm{N})$, mean values with their respective standard deviations. There was a significant difference in mercury concentration in feathers of birds collected from the 3 study locations, $\mathrm{F}(2,27)=54.66, \mathrm{P}<0.01, \mathrm{n}_{\mathrm{p}}^{2}=0.80$. Post hoc testing revealed significant differences in mercury concentration in feathers with Daudu (Mean=3.76, $\mathrm{SD}=1.50$ ) having higher mercury concentration in feathers whereas Buruku (Mean=0.13, $\mathrm{SD}=0.40$ ) and Adega (Mean $=0.12, \mathrm{SD}=0.37$ ) had a lower mercury concentration (Table 1 ). This shows that birds from Daudu had more mercury concentration in feathers.

Table I Summary of Mercury concentration $(\mathrm{mg} / \mathrm{kg})$ in selected organs of Black-headed orioles trapped from Benue State, Nigeria

\begin{tabular}{lllll}
\hline Study locations & & & & \\
\hline Organs & N & Buruku & Daudu & Adega \\
\hline Feathers & 30 & $0.13 \pm 0.40^{\mathrm{b}}$ & $3.76 \pm 1.46^{\mathrm{a}}$ & $0.12 \pm 0.37^{\mathrm{b}}$ \\
Liver & 30 & $0.12 \pm 0.37$ & $0.71 \pm 1.29$ & 0 \\
Heart & 30 & $0.00 \pm 0.00$ & $0.00 \pm 0.00$ & 0 \\
Skin & 30 & $0.00 \pm 0.00^{\mathrm{b}}$ & $0.43 \pm 0.67^{\mathrm{a}}$ & $0.00 \pm 0.00^{\mathrm{b}}$ \\
Carcass & 30 & $9.74 \pm 1.64^{\mathrm{b}}$ & $7.05 \pm 1.52^{\mathrm{a}}$ & $0.00 \pm 0.00^{\mathrm{c}}$ \\
Eggs & 9 & $0.00 \pm 0.00^{\mathrm{b}}$ & $0.11 \pm 0.02^{\mathrm{a}}$ & $0.00 \pm 0.00^{\mathrm{b}}$ \\
Nestling feathers & 9 & $0.00 \pm 0.00^{\mathrm{b}}$ & $3.80 \pm 1.50^{\mathrm{a}}$ & $0.00 \pm 0.00^{\mathrm{b}}$ \\
\hline
\end{tabular}

**Mean with different alphabet within the row differs significantly $(P<0.05)$.

There was no significant difference in mercury concentration in liver of birds trapped from the 3 study locations, $F(2,27)=2.42$, $\mathrm{P}>0.05, \mathrm{n}_{\mathrm{p}}^{2}=0.15$. Post hoc testing revealed no significant differences in mercury concentration in liver with Daudu (Mean $=0.71, \mathrm{SD}=1.30$ ), Buruku (Mean=0.12, $\mathrm{SD}=0.37$ ) and Adega (Mean=0.00, $\mathrm{SD}=0.00$ ) having the same mercury concentration (Table 1). This shows that birds from Daudu, Buruku and Adega had equal mercury concentration in liver because the liver serves as storage organs for toxic substances. However, mercury concentration in the hearts was below detection limits in the 3 study locations (Table 1). There was a significant difference in mercury concentration in skin of birds trapped from the 3 study locations, $\mathrm{F}(2,27)=4.49, \mathrm{P}<0.05, \mathrm{n}^{2}=0.25$. Post hoc testing revealed significant differences in mercury concentration in skin with Daudu (Mean $=0.43, \mathrm{SD}=0.67$ ) having a higher mercury concentration whereas Buruku (Mean $=0.00, \mathrm{SD}=0.00$ ) and Adega (Mean $=0.00$, $\mathrm{SD}=0.00$ ) had a lower mercury concentration (Table 1 ). This shows that birds from Daudu had more mercury concentration in skin. 
There was a significant difference in mercury concentration in carcass of birds trapped from the 3 study locations, $F(2,27)=151.84$, $\mathrm{P}<0.01, \mathrm{n}_{\mathrm{p}}^{2}=0.92$. Post hoc testing revealed significant differences in mercury concentration in carcass with Daudu (Mean=7.05, $\mathrm{SD}=1.52$ ) having a higher mercury concentration whereas Buruku (Mean=9.74, $\mathrm{SD}=1.64$ ) had moderate concentration and Adega (Mean=0.00, $\mathrm{SD}=0.00$ ) had a lower mercury concentration (Table 1). However, this finding indicates birds from Daudu had more mercury concentration in carcass. There was a significant difference in mercury concentration in eggs of birds collected from the 3 study locations, $F(2,6)=78.77$, $\mathrm{P}<0.01, \mathrm{n}_{\mathrm{p}}^{2}=0.96$. Post hoc testing revealed significant differences in mercury concentration in eggs with Daudu (Mean $=0.11, \mathrm{SD}=0.02$ ) having a higher mercury concentration whereas Buruku (Mean $=0.00$, $\mathrm{SD}=0.00$ ) and Adega (Mean $=0.00, \mathrm{SD}=0.00$ ) had a lower mercury concentration (Table 1). However, this finding indicates birds from Daudu had more mercury concentration in eggs. There was a significant difference in mercury concentration in nestling feathers of birds trapped from the 3 study locations, $\mathrm{F}(2,6)=19.96, \mathrm{P}<0.01$, $\mathrm{n}^{2}=0.87$. Post hoc testing revealed significant differences in mercury concentration in nestling feathers with Daudu (Mean=3.80, $\mathrm{SD}=1.47$ ) having a higher mercury concentration whereas Buruku (Mean $=0.00$, $\mathrm{SD}=0.00$ ) and Adega (Mean=0.00, $\mathrm{SD}=0.00$ ) had a lower mercury concentration (Table 1). However, this finding indicates birds from Daudu had more mercury concentration in nestling feathers (Table 1).
However, Table 2 shows very high significant correlation $\left(r^{2}=0.810\right)$ between mercury concentration in the feather and mercury concentration in the carcass $(\mathrm{P}<0.01)$ whereas a very high significant negative correlation $\left(\mathrm{r}^{2}=-0.997\right)$ also existed between mercury concentration in the carcass and mercury concentration in the liver of the said species $(\mathrm{P}<0.05)$ (Table 2). A total of 27 crop samples were collected from Buruku, Daudu and Adega in Benue State for mercury concentration investigation and its concentration in maize harvested directly from farmland in Buruku was below detection limit whereas mercury concentration in maize harvested from Daudu ranged from $2.53-2.53 \mathrm{mg} / \mathrm{kg}$ with a mean of $2.53 \pm 0.00 \mathrm{mg} / \mathrm{kg}$, but mercury concentration in maize harvested from Adega was below detection limit. Therefore, Daudu has the highest mercury concentration in maize (Table 3). Mercury concentration $(\mathrm{mg} / \mathrm{kg}$ ) in rice harvested directly from farmland in Buruku, Daudu and Adega were below detection limit using atomic absorption spectrophotometer (AAS). Mercury concentration $(\mathrm{mg} / \mathrm{kg})$ in guinea corn harvested directly from farmland in Buruku was below detection limit whereas mercury concentration in guinea corn harvested from Daudu ranged from 0.42$4.74 \mathrm{mg} / \mathrm{kg}$ with a mean of $4.58 \pm 0.23 \mathrm{mg} / \mathrm{kg}$, making it the highest mercury concentration in the guinea corn harvested from the study areas but mercury concentration in guinea corn harvested from Adega was below detection limit using atomic absorption spectrophotometer (AAS) (Table 3).

Table 2 Correlation between wet weight of different organs and mercury concentrations in different organs

\begin{tabular}{lllllllll}
\hline & WF & WC & WL & WS & HgCF & HgCC & HgCL & HgCS \\
\hline WF & & & & & & & & \\
WC & 0.54 & & & & & & \\
WL & -0.272 & -0.104 & & & & & \\
WS & -0.151 & -0.348 & 0.593 & & & & \\
HgCF & 0.165 & 0.194 & -0.043 & -0.471 & & & \\
HgCC & -0.194 & -0.203 & 0.046 & -0.378 & $0.810^{* *}$ & & \\
HgCL & 0.915 & 0.878 & -0.564 & 0.397 & -0.56 & $-0.997^{*}$ & \\
Hg CS & -0.572 & 0.302 & -0.919 & -0.977 & 0.92 & 0.115 & -0.192 &
\end{tabular}

$* *=(\mathrm{P}<0.01) ; *=(\mathrm{P}<0.05)$

Table 3 Summary statistics of mercury concentration $(\mathrm{mg} / \mathrm{kg})$ in crops harvested from the study locations

\begin{tabular}{lllll}
\hline Locations & N & Mean \pm SD & Minimum & Maximum \\
\hline Buruku & & & & \\
\hline Maize & 3 & $* *$ & $* *$ & $* *$ \\
Rice Oryza Sativa & 3 & $* *$ & $* *$ & $* *$ \\
Guinea Corn & 3 & $* *$ & $* *$ & $* *$ \\
\hline Daudu & & & & \\
\hline Maize & 3 & $2.53 \pm 0.00$ & 2.53 & 2.53 \\
Rice Oryza Sativa & 3 & $* *$ & $* *$ & $* *$ \\
Guinea Corn & 3 & $4.58 \pm 0.23$ & 0.42 & 4.74 \\
\hline Adega & & & & \\
\hline Maize & 3 & $* *$ & $* *$ & $*$ \\
Rice Oryza Sativa & 3 & $* *$ & $* *$ & $*$ \\
Guinea Corn & 3 & $* *$ & $* *$ &
\end{tabular}

** Not Detected. 
For my analysis, a total of nine soil samples and nine water samples were collected from different location in Benue State for mercury concentration investigation (Figure $1 \& 2$ ). Apart from that soil samples from Buruku ranged from below detection limit to $0.82 \mathrm{mg} /$ $\mathrm{kg}$, whereas Daudu has mercury concentration that ranged from 7.58$8.53 \mathrm{mg} / \mathrm{kg}$ and a samples from Adega were below detection limit (Figure 1). Water samples from Buruku range from below detection limit to $0.05 \mathrm{mg} / \mathrm{l}$, whereas mercury concentration in water samples collected from Daudu ranged from $0.06-0.09 \mathrm{mg} / 1$. Whereas water samples from Adega were below detection limit (Figure 2). Therefore, water samples from Daudu had the highest mercury concentration of $0.09 \mathrm{mg} / \mathrm{l}$.

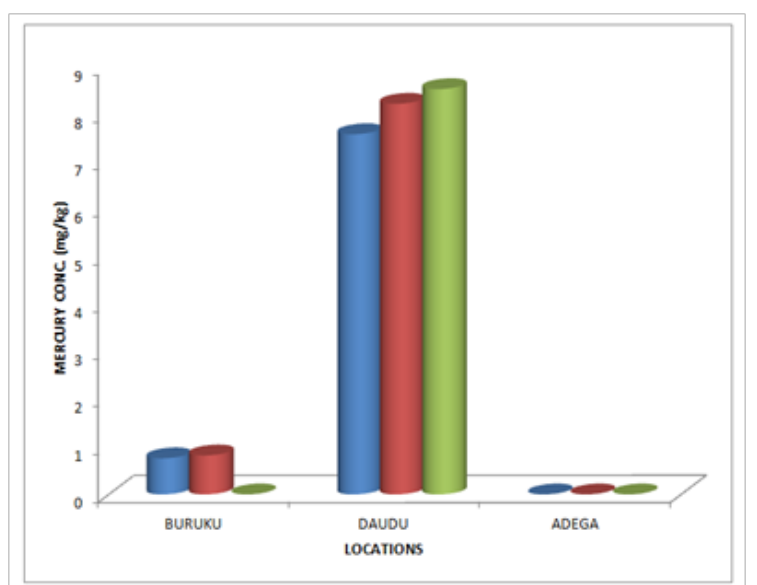

Figure I Mercury concentration in soil samples collected from different locations in Benue State.

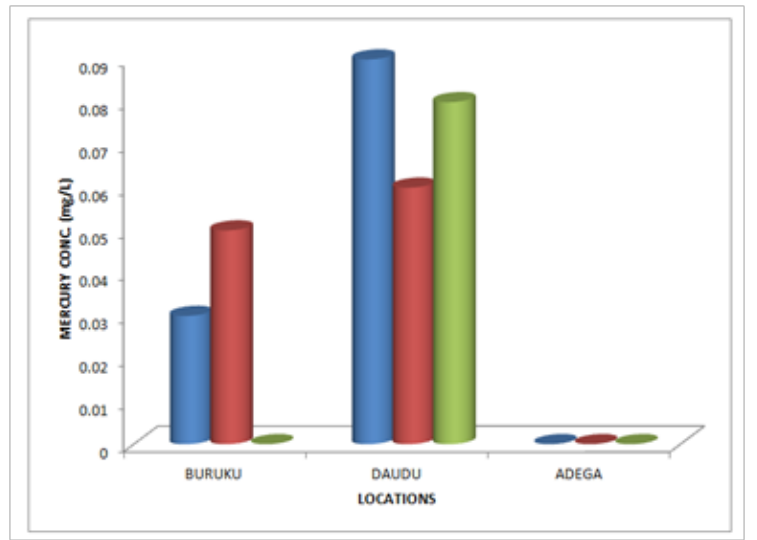

Figure 2 Mercury concentration in water samples collected from different locations in Benue State.

\section{Discussion}

The distribution of mercury among the various organs is not uniform but to some extent it also accumulated in specific target organs such as the feathers, carcass, nestling feathers liver, skin and egg in a decreasing order. This research finding is in agreement with the report of ${ }^{21}$ who reported that feather as a distinct organ is known for accumulation of mercury especially during the period of feather growth. When molting is completed, the level of mercury concentration in the feather remains stable, even if the bird feeds on contaminated food. According to, ${ }^{22}$ mercury content in feathers may represents up to $93 \%$ of the accumulated body load of contaminant which is in agreement with mercury concentration recorded in this current work. This finding is also in agreement with the research work of ${ }^{23}$ who reported the largest average concentration of mercury in the feather. However, this work is at variance with the report of ${ }^{24}$ who reported a lower mercury concentration of $4.539 \mathrm{mg} / \mathrm{kg}$ in an individual species of Eurasian Buzzard, found wounded after crash with high tension wire lines in Poland. It is also at variance with the research work reported by Falandysz ${ }^{25}$ who recorded higher mercury concentration with an arithmetic mean of $52.0 \pm 16.0 \mathrm{mg} / \mathrm{kg}$ in White-tailed Sea Eagles from the Baltic South Coast in Poland. In addition, this current work is equally at variance with the work of ${ }^{3}$ who reported a lower mercury concentration of $0.380 \pm 0.047 \mathrm{mg} / \mathrm{kg}$ in feather of Greylag goose in Iran. In the same manner, a higher level of mercury in bird species were recorded compared to the report of ${ }^{26}$ who reported mercury concentration of $3.18 \pm 4.99 \mathrm{mg} / \mathrm{kg}$ in Ural Owl from industrial vicinity of Tokyo in Japan which is more of a contaminated environment. Similarly, this work is also at variance with the report who reported a lower mercury concentration of $0.09 \mathrm{mg} / \mathrm{kg}$ in domestic fowl in Egypt. The differences in mercury concentration recorded in this current work and those cited from literature is due to differences in species, foraging behaviour, location and nature of anthropogenic activities. $^{27}$

The total recommended mercury concentration in animals by WHO is $0.5 \mathrm{mg} / \mathrm{kg},{ }^{28}$ however the permissible limit in wild birds has been exceeded. The difference in mercury concentration in bird species is dependent on the interval of exposure, the quantity of ingested constituent, age of the bird species, foraging behaviour and as well as the foraging environment. This is in consonance with the findings of. ${ }^{29,30}$ Metal toxicity may be affected by the route and form of ingestion as well as the interaction between essential and toxic elements in the environment ${ }^{30,31}$ during ecological and foraging proceedings. This is in agreement with the research finding which demonstrated a significant correlation between mercury concentration in the carcass and mercury concentration in the feathers of Black headed oriole trapped from the study locations. This shows that mercury concentration in the feather may have accumulated directly from consumption of feed from the said environment because the concentration in crop plant collected from the environment has exceeded the permissible limit which is an indicator of pollution. It is striking that the variation in many cases is higher than the mean of the liver due to high standard deviation. Therefore, there was no significant difference but a substantial variation existed, making biological interpretation of the result obtained from the liver difficult. This current research work also recorded a higher mercury concentration in maize and guinea corn compared to the work of, ${ }^{32}$ who reported mercury concentration of $0.127 \mathrm{mg} / \mathrm{kg}$ in rice harvested directly from farmland in China and the result findings indicated the permissible limit in cereal crops has been exceeded.

This current research work recorded a lower mercury concentration in soil compared to the work of, ${ }^{32}$ who reported mercury concentration of $289 \mathrm{mg} / \mathrm{kg}$ in contaminated soil in China. Soil conditions in general are conducive for the formation of inorganic compounds such as mercury chloride $(\mathrm{HgCl})$, mercury hydroxide $(\mathrm{HgOH})$ and inorganic mercury (II) compounds, which are capable of forming complexes with organic anions. This complex behaviour limits mobility of mercury in soil so that much of the mercury in soil usually sticks to bulk organic matter and they are easily subjected to surface runoff during excessive rainfall because they are only attached to suspended soil or humus. This could be responsible for presence of mercury in surface water from the study locations being a farmland with little vegetation cover. Apart from that, mercury can also be released by evaporation of mentholated mercury to the atmosphere from soils ${ }^{33}$ 
which may invariably be incorporated into surface water during rainfall because contaminants are basically not localized especially in scanty vegetation. Mercury concentrations in this study have exceeded the permissible contaminant level of $2 \mathrm{mg} / \mathrm{L}$ set by the US Environmental Protection Agency for drinking-water. ${ }^{34}$ The likely factors responsible for presence of high mercury load recorded in birds of the study localities could be attributed to natural occurrence of mercury in soils and sediments, in addition annual flooding and agricultural activities through pesticide application, burning of refuse in dumpsite, and open defecation by travelers beside the road because metal accumulation could be added to the environment through fecal It was also reported by $\mathrm{WHO},{ }^{34}$ that an experimental rat injected continuously 3 times weekly for up to a period of 8 months with doses of inorganic mercury ranging from 0.05 to $2.5 \mathrm{mg} / \mathrm{kg}$ of body weight per injection $(0.02-1.07 \mathrm{mg} / \mathrm{kg}$ of body weight per day) developed renal damage and according to,${ }^{35}$ the possible noticeable effects of mercury in birds are decreased egg weight, fertility, and hatchability. Increase in kidney lesions, brain lesions, skeletal deformities; reduced clutch size, poor hatchability, poor embryonic growth, behavioral change and neurologic signs of weakness and inadequate coordination in wild birds.

\section{Conclusion and recommendation}

The bioaccumulation level of mercury in the study species coupled with the concentration in grains and water calls for concern because wild birds have decreased considerable in recent time. Therefore, analysis of lead, selenium and organochloride should be carried out to determine their accumulation in organs of wild birds since the study areas are agrarian communities.

\section{Acknowledgements}

None.

\section{Conflict of interest}

The author declares no conflicts of interest.

\section{References}

1. Pirrone N, Cinnirella S, Feng $\mathrm{X}$, et al. Global mercury emissions to the atmosphere from anthropogenic and natural sources. Atmos Chem Phys. 2010;10:5951-5964.

2. Streets DG, Zhang Q, Wu Y. Projection of global mercury emissions in 2050. Environ Sci Technol. 2009;43(8):2983-2988.

3. Ahmadpour M, Lan Hai L, Ahmadpour M, et al. Mercury concentration in the feathers of birds from various trophic levels in Fereydunkenar International wetland (Iran). Environ Monit Assess. 2016;188(12):666

4. Roux KE, Marra PP. The presence and impact of environmental lead in passerine birds along an urban to rural land use gradient. Arch Environ Contam Toxicol. 2007;53(2):261-268.

5. Burger J, Gochfeld M. Mercury and other metals in feathers of common eider (Somateria mollissima) and tufted puffin (Fratercula cirrhata) from the Aleutian chain of Alaska. Arch Environ Contam Toxicol. 2009;56(3):596-606.

6. Karadede H, Oymak SA, Unlü E. Heavy metals in mullet, Liza abu and catfish, Silurus triostegus, from the Ataturk Dam Lake (Euphrates), Turkey. Environ Int. 2004;30(2):183-188.

7. Kaoud HA, El Dahshan AR. Bioaccumulation and histopathological alterations of the heavy metals in Oreochromis niloticus fish. Nature and Science. 2010;8(4):1-10
8. Jayasena N, Frederick PC, Larkin IL. Endocrine disruption in white ibises (Eudocimus albus) caused by ex-posure to environmentally relevant levels of methylmercury. Aquat Toxicol. 2011;105(3-4):321-327.

9. Heath JA, Frederick PC. Relationships among mercury concentrations, hormones, and nesting effort of white ibises (Eudocimus albus) in the Florida everglades. The Auk. 2005;122(1):255-267.

10. Frederick P, Jayasena N.Altered pairing behavior and reproductive success in white ibises exposed to environmentally relevant concentrations of methyl mercury. Proc Biol Sci. 2011;278(1713):1851-1857.

11. Hallinger KK, Zabransky DJ, Kazmer KA, et al. Song differs between birds on mercury-polluted and reference sites. The Auk. 2010;127:156161 .

12. Egwumah PO, Egwumah FA. Effect of woody vegetation on grassland birds in Ikwe Wildlife Park. International Journal of Development and Sustainability. 2014;3(3):547-553.

13. Johnson DH, Igl LD. Area Requirements of Grassland Birds: A regional perspective. Auk. 2001;118(1):244-234

14. Dauwe T, Bervoets L, Blust R, et al. Can excrement and feathers of nestling songbirds be used as biomonitors for heavy metals pollution. Arch Environ Contam Toxicol. 2000;39(4):541-546.

15. Markowski M, Kaliński A, Skwarska J, et al. Avian Feathers as Bioindicators of the Exposure to Heavy Metal Contamination of Food. Bull Environ Contam Toxicol. 2013;91(3):302-305.

16. Rothenberg SE, Feng X, Dong B, et al. Characterization of mercury species in brown and white rice (Oryza sativa L.) grown in water-saving paddies. Environmental Pollution. 2011;159:1283-1289.

17. Denscombe M. Research guide for small-scale social research projects. 4th ed. USA: McGraw Hill Open University Press; 2010. p. 34-53.

18. Onuwa PO, Nnamonu LA, Eneji IS, et al. Analysis of Heavy Metals in Human Scalp Hair Using Energy Dispersive X-Ray Fluorescence Technique Journal of Analytical Sciences. Methods and Instrumentation. 2012;2:187-193.

19. Edison B, Carlos ABG, Elisangela DP, et al. Heavy metal concentration in tissues of Puffinus gravis sampled on the Brazilian coast. Revista Brasileira de Ornitologia. 2007;15(1):69-72.

20. Egwumah FA, Egwumah PO, Tyowua BT. Evaluation of Black-Headed Oriole Oriolus brachyrhynchus (Swainson, 1837) as Bioindicator of Arsenic Contamination Using Atomic Absorption Spectrometry (AAS). Journal of Agriculture and Ecology Research International. 2017;12(3):1-9.

21. Tsipoura N, Burger J, Newhouse M, et al. Lead, mercury, cadmium, chromium, and arsenic levels in eggs, feathers, and tissues of Canada geese of the New Jersey meadowlands. Environ Res. 2011;111(6):775784

22. Bearhop S, Ruxton GD, Furness RW. Dynamics of mercury in blood and feathers of great skuas. Environmental Toxicology and Chemistry. 2000;1:638-643.

23. Terra BF, Araújo FG, Calza CF, et al. Heavy Metal in Tissues of Three Fish Species from Different Trophic Levels in a Tropical Brazilian River. Water Air Soil Pollution. 2007;187(1-4):275-284.

24. Komosa A, Kitowski I, Kowalski R, et al. Total mercury concentration in kidneys of birds of prey from different part of Poland - some interspecies and geographical differences. Ecological Chemistry and Engineering Science. 2009:16(S1).

25. Falandysz J, Ichihashi HI, Szymczyk K, et al. Metallic Elements and Metal Poisoning among White-tailed Sea Eagles from the Baltic South Coast. Marine Pollut Bull. 2001;42:1190-1193. 
26. Horai S, Wanatabe I, Takada H, et al. Trace element accumulation in 13 avian species collected from Kanto area, Japan. Science of Total Environment. 2007;373(2-3):512-525.

27. Alturiqi AS, Albedair LA. Evaluation of some heavy metals in certain fish, meat and meat products in Saudi Arabian markets. Egyptian Journal of Aquatic Research. 2012;2(38):45-49.

28. Abrahamsson E, Ekelund M. Human Exposure from Mercury in Rice in the Philippines. Sweden: Uppsala University; 2014. p. 1-19.

29. Massányi P, Trand J, Lukáč N, et al. The contamination of bovine semen with $\mathrm{Cd}, \mathrm{Pb}, \mathrm{Cu}$ and $\mathrm{Zn}$ and its relation to the quality of spermatozoa used for insemination. Folia Veterinari. 2000;44(3):150-153.

30. Mahmoud MAM, Abdel Mohsein HS. Health risk assessment of heavy metals for Egyptian population via consumption of poultry edibles. $A d v$ Anim Vet Sci. 2015;3(1):58-70.
31. Skalická M, Koréneková B, Nad P. Distribution of trace elements in liver and muscle of Japanese quails. Slovak Journal of Animal Science. 2008;41(4):187-189.

32. Horvat M, Nolde N, Fajon V, et al. Total mercury, methylmercury and selenium in mercury polluted areas in the province Guizhou, China. Sci Total Environ. 2003;304(1-3):231-256.

33. World Health Organization. Heavy Metals in Waste Final Report. Belgium: European Commission; 2002.

34. World Health Organization. Mercury in Drinking-water. Background document for development of WHO Guidelines for Drinking-water Quality. 2005.

35. Resaee A, Derayat J, Mortazavi SB, et al. Removal of Mercury from chlor-alkali industry wastewater using Acetobacter xylinum cellulose. American Journal of Environmental Sciences. 2005;1(2):102-105. 